\title{
THE USE OF ENGLISH ARTICLES BY A GROUP OF EFL LEARNERS
}

\author{
Leyla Hasbún Hasbún
}

\begin{abstract}
RESUMEN
Este estudio analiza la producción escrita de un grupo de estudiantes de inglés como lengua extranjera con el fin de determinar los errores en que incurren en lo que respecta al uso de los artículos de la lengua inglesa. Los resultados muestran que el tipo más común de error en todos los niveles tiende a ser el uso excesivo de los artículos. Esto sucedió en seis de los ocho grupos estudiados. Este tipo representa entre el 40.0 y el $58.82 \%$ de los errores. Se postula que al menos en parte esto se debe a interferencia de la lengua materna. Hay evidencia de que este uso excesivo tiende a disminuir a medida que los estudiantes mejoran su competencia lingüística.

Palabras claves: artículos, adquisición, errores, interferencia, inglés como lengua extranjera.
\end{abstract}

\begin{abstract}
This study analyzes the written production of a group of English-as-a-foreign-language students in order to determine the errors concerning the use of articles that students make. Results show that the most common type of mistake in all levels tends to be the overuse of articles. This happened in six out of eight groups. This type of mistake represents from 40 to $58.82 \%$ of the article errors. The article claims that this is partly due to first language interference. There is also evidence that indicates that overuse tends to decrease but not in a significant way.

Key words: articles, acquisition, errors, interference, English as a foreign language.
\end{abstract}

The English article system is an elusive aspect of English grammar. It includes the indefinite article $a(n)$, the definite article the, and the zero or null article, e.i., instances in which a noun requires no article. Undoubtedly, the article system is especially difficult for those learners whose native language does not have articles, as is the case in many

\footnotetext{
Dra. Leyla Hasbún Hasbún. Profesora. Programa de Posgrado en la Enseñanza del Inglés. Escuela de Lenguas Modernas. Universidad de Costa Rica

Correo electrónico: leyla.hasbun@ucr.ac.cr
}

Recepción: 2- 3- 2009

Aceptación: 14- 4- 2009 
languages of the world such as Russian, Polish or Chinese. However, research has shown that the acquisition of articles is challenging even for those learners whose L1s, like Spanish, employ them.

Master (1990:461) asserts that dealing with the article system is demanding for learners of English, because, first of all, articles are frequently unstressed or "invisible" (zero or null article), and therefore, they are not salient in the input. In addition, the misuse of articles rarely causes confusion in oral communication; consequently, learners are not required to become fully aware of their appropriate use because they can manage without them. These two characteristics delay acquisition. In a more recent article, Master (2002:332) expands his account of article difficulty. First of all, he reiterates that articles are usually unstressed and sometimes invisible, and consequently, they are very difficult to discriminate in spoken discourse. ${ }^{11} \mathrm{He}$ adds that they are among the most frequently used function words in English, which makes the constant, conscious application of rules in extended discourse intricate. Finally, Master explains that, in the article system, a single morpheme serves many functions, e.g., definiteness, countability and number. This is a very complex situation since the natural human tendency is to expect a one-form-one function correspondence.

Since the article system is indisputably difficult, teachers often wonder how to best guide their learners through the intricacies of the acquisition process. They consider multiple options to make acquisition less painful. What is more, they sometimes question the effectiveness of pedagogic intervention, that is, whether instruction really makes a difference. For example, in a discussion of the teaching implications derived from the research findings available at the time, Dulay, Burt and Krashen recommend devoting some time to formal grammar lessons for adults but advise teachers to

\footnotetext{
focus on low-level, easy rules, not complex ones, e.g. the it's / its distinction is a low-level rule. On the other hand, the definite / indefinite $a$ / the distinction seems to resist explicit instruction. The rules governing the use of $a$ and the are so complex, they are not adequately stated in many grammar books. This distinction will be acquired subconsciously, if it is acquired at all. (1982: 267)
}

Doughty and Williams (1998: 201) concur. They claim that "there are some forms, such as the English article system that seem strangely impermeable to instruction and so, for that reason alone, perhaps should not take up valuable class time." Other researchers and teachers, however, have a more optimistic view. Master (1994: 248) concludes that "language instruction is beneficial if that instruction is based on a systematic presentation of the material, that is, when the material is presented in a hierarchy of manageable segments with continuous building on what has been taught before."

For the teaching of the articles, Master (1990) offers a straightforward binary distinction between classification (a/an or $\theta$ ) and identification (the), which collapses other features used in formal linguistics. Classification $\underline{22}$ includes the features [- definite] [- specific] and identification ${ }^{33}$ comprises [+ definite] [+ specific]. Frodesen \& Eyring (2003: 78) follow Master (1990) and explain that "an indefinite article (a/an or $\Theta$ ) classifies a noun and shows that it represents or reflects a type, group, or a class distinct from some other type, group or class," while the definite article the can "identify a noun and show that it has been singled out in some way." Table 1 summarizes these concepts in the way that modern ESL/EFL textbooks present them. 
Table 1: Pedagogical Tools for the Teaching of Articles

\begin{tabular}{|c|c|}
\hline \multicolumn{2}{|c|}{$\begin{array}{l}\text { Pedagogical Tools for the Teaching of Articles } \\
\text { rodesen, J. \& Eyring, J. (2003) Grammar dimensions } 4 a \text {, p.78. }\end{array}$} \\
\hline $\begin{array}{c}\text { Classification } \\
\text { [- definite] [-specific] } \\
\text { Shows a kind, type, class or group }\end{array}$ & $\begin{array}{c}\text { Identification } \\
{[+ \text { definite }][+ \text { specific }]} \\
\text { Shows a specific feature, aspect, characteristic }\end{array}$ \\
\hline $\begin{array}{l}\mathrm{A} \longrightarrow \text { singular noun } \\
\mathrm{I} \text { need a raincoat. } \\
\mathrm{An} \longrightarrow \text { singular noun } \\
\text { Ann needs an umbrella. } \\
\Theta \longrightarrow \text { non-count noun } \\
\text { We need } \Theta \text { clothes. }\end{array}$ & $\begin{array}{l}\text { The } \longrightarrow \text { singular noun } \\
\qquad \longrightarrow \text { plural noun } \\
\qquad \longrightarrow \text { non-count noun } \\
\text { The raincoat on the sofa is Mary's. } \\
\text { The umbrella I bought is green. } \\
\text { The clothes she is wearing are expensive. }\end{array}$ \\
\hline $\begin{array}{l}\text { Answers the question "What?" } \\
\text { What do you need? } \\
\text { A raincoat. }\end{array}$ & $\begin{array}{l}\text { Answers the question "Which?" } \\
\text { Which raincoat? } \\
\text { The raincoat on the sofa. }\end{array}$ \\
\hline
\end{tabular}

Master (1990) believes that pedagogical tools such as the one above allow for a one form / one function correspondence for the articles $a$ and the, i.e., "a straightforward rule of thumb that accounts for article usage in the greatest number of cases" (465). He explains that the major limitation of this categorization is that proper nouns and idiomatic expressions need to be covered separately (466). However, a significant advantage is that the terms identified and classified are far more inclusive than definiteness, and although they reduce descriptive adequacy, they effectively explain the article system for educational and psychological purposes.

The definite article has a generic uses for a class of entities rather than a specific member of a class, and non-generic uses, the latter being wider and more frequent. Hawkins' (1978) developed his location theory, which provides a helpful interpretation of the nongeneric meaning of the definite article in English. He asserts that all instances of nongeneric the can be grouped into eight general categories. Celce-Murcia and Larsen-Freeman (1999: 279) summarize Hawkins' theory as follows: "When a speaker / writer uses the, he instructs the hearer / reader to locate the referent in the same shared mental set of objects." Table 1 recapitulates Hawkins' ideas as elucidated by Liu and Gleason (2002: 6) and García Mayo (2008: 552) who conducted studies on the acquisition of nongeneric the.

Table 2: Hawkins' (1978) Location Theory: Uses of nongeneric the

\begin{tabular}{|c|c|c|}
\hline Type of Use & Use of the & Example \\
\hline 1. Anaphoric & $\begin{array}{l}\text { When something is mentioned a } \\
\text { second time and subsequently }\end{array}$ & $\begin{array}{l}\text { Bill was working at a lathe the } \\
\text { other day. All of a sudden the } \\
\text { machines stopped running. }\end{array}$ \\
\hline 2. Visible situation & $\begin{array}{l}\text { With a noun mentioned the first } \\
\text { time to refer to something that } \\
\text { both the speaker and the listener } \\
\text { can see. }\end{array}$ & Pass me the bucket. \\
\hline 3. Immediate situation & $\begin{array}{l}\text { Similar to type } 2 \text {, except that the } \\
\text { thing referred to may not be visible }\end{array}$ & $\begin{array}{l}\text { Don't go in there, chum. The dog } \\
\text { will bite you. }\end{array}$ \\
\hline $\begin{array}{l}\text { 4. Larger situation relying on } \\
\text { specific knowledge }\end{array}$ & $\begin{array}{l}\text { With a first-mention noun because } \\
\text { it is known in the community }\end{array}$ & $\begin{array}{l}\text { People from the same village tal- } \\
\text { king about the church, the pub, etc. }\end{array}$ \\
\hline
\end{tabular}




\begin{tabular}{|l|l|l|}
\hline $\begin{array}{l}\text { 5. Larger situation relying on } \\
\text { general knowledge }\end{array}$ & $\begin{array}{l}\text { With something that one can } \\
\text { assume people from a country or } \\
\text { around the world should know }\end{array}$ & The White House, the moon \\
\hline 6. Associative anaphoric & $\begin{array}{l}\text { The same as type 1, except that } \\
\text { the first-mention the is used with a } \\
\text { noun that is related to a previously } \\
\text { mentioned noun, rather than being } \\
\text { the same noun }\end{array}$ & $\begin{array}{l}\text { We went to a wedding. The bride } \\
\text { was very tall. }\end{array}$ \\
\hline $\begin{array}{l}\text { 7. Unfamiliar use in NPs with } \\
\text { explanatory modifiers }\end{array}$ & $\begin{array}{l}\text { With a first-mention noun that } \\
\text { has an explanatory or identifying } \\
\text { modifier in the form of a clause, } \\
\text { prepositional phrase or noun. }\end{array}$ & $\begin{array}{l}\text { The movies that are shown here } \\
\text { now are all rated R. There was a } \\
\text { funny story on the front page of } \\
\text { the Guardian this morning. I hate } \\
\text { the name Algernon. }\end{array}$ \\
\hline $\begin{array}{l}\text { 8. Unfamiliar use in NPs with } \\
\text { non-explanatory modifiers }\end{array}$ & $\begin{array}{l}\text { Similar to type 7, except that } \\
\text { the modifier does not provide } \\
\text { explanatory information }\end{array}$ & $\begin{array}{l}\text { My wife and I share the same } \\
\text { secrets, where the modifier same } \\
\text { does not identify the secrets. Here } \\
\text { same is used as a unique adjective } \\
\text { that always requires the. }\end{array}$ \\
\hline
\end{tabular}

Liu and Gleason (2002) utilized Hawkins' (1978) Location Theory as a point of departure to classify the nongeneric uses of the article the. Instead of using the eight original categories proposed by Hawkins, the authors collapsed them to four major uses: cultural, situation, structural and textual. In order to find out whether these uses present different levels of difficulty, they designed an instrument that consisted of 91sentences containing deleted obligatory uses of the article the as well as distracters that required zero articles, that is, instances in which a noun requires no article. The participants, who were ESL college learners and who were mostly East Asian, were asked to read the sentences and insert the wherever necessary. The authors concluded that the four nongeneric uses pose different levels of difficulty, which suggests that the acquisition of the different uses follows a natural order. These ESL learners seemed to have acquired situation use first, cultural use last, and structural and textual uses in between. Secondly, the suppliance of the in obligatory contexts for all the uses improved significantly with proficiency level whereas the overuse of the showed an initial worsening followed by an improvement as the students' proficiency level increased. The first pedagogical implication proposed by Liu and Gleason (2002) is that classroom teaching practice and instructional materials should reflect this natural order of acquisition. The authors suggest beginning with the situation use of the, where the teacher can easily apply the principle of here-and-now, and postponing the cultural uses and treating them as frozen lexical items following the Lexical Approach. (For a detailed explanation of this approach, see Nattinger and DeCarrico 1992 and Schmitt 2000). Secondly, Liu and Gleason believe that, in order to make instruction effective, different sensory channels should be employed. For instance, the teaching of the situation use should include kinesthetic, auditory, tactile and visual learning. With structural and textual use, more cognitive learning may be needed since these two uses involve the ability to analyze structural and textual information. The cultural use requires cognitive learning and a great deal of memorization because such use entails the application of many rules which are often very complex. Finally, since students naturally go from underuse to overuse and finally to appropriate use, teachers need to be patient and give learners time to be ready for the acquisition of the article system.

García Mayo (2008) replicated the study by Liu and Gleason (2002). In order to overcome one of the limitations acknowledged by the authors, namely, that the majority of their learners spoke 
Chinese, Korean and Japanese, East Asian languages that have no articles, García Mayo selected EFL learners who were native speakers of Spanish, a language that "has definite articles with a similar semantic / pragmatic context of use to that of English for the four uses of the nongeneric definite article" (555). In addition, she used a different proficiency measure. The difficulty hierarchy proposed by Liu and Gleason for ESL was validated for EFL students, whose native language has articles. García Mayo also concluded that the participants' overuse of the decreased significantly as their English proficiency improved for all the groups and that all instances of definite article overuse found were due to transfer from Spanish. This finding is not in line with the results obtained by Liu and Gleason. As to pedagogical implications, García Mayo agrees with Liu and Gleason in that it is a good idea to teach the easiest uses first, but she argues that teachers should provide plenty of practice on the two most difficult categories in the hierarchy. Furthermore, the author recommends providing metalinguistic feedback and using form-focused tasks. ${ }^{44}$ These two activities, which promote learner awareness of target grammar forms, are recognized in the literature as helpful for input processing (see for example Pica, 2007); nevertheless, Fotos and Hinkel (2007: 131-32) assert that "meaningful input alone, even enhanced input, does not promote the development of target-like L2 accuracy. Both grammar instruction and opportunities for output are now seen as additional requirements."

\section{The current study}

The School of Modern Languages where the study was conducted has been going through a process of accreditation for the past few years. This process of self-examination has identified a paucity of research on the specific language difficulties that the students need to overcome. In an attempt to at least partially solve this problem, the author has conducted a series of studies whose main goal has been to determine the actual shortcomings in the learners' written production as well as to identify teachers' and students' beliefs concerning problematic language areas. In the first study (Hasbún 2007), the author concluded that, although the frequency of certain grammar errors increases and decreases unpredictably across levels, errors pertaining to subject omission, subject verb agreement and negative forms tend to be more common in beginners. In addition, the three most frequent types of grammar errors learners across levels made were related to the incorrect use of articles, prepositions and verb forms. In the second study (Hasbún 2009) results indicated that teachers underestimate the frequency of certain grammar errors. For example, half of the teachers failed to identify articles as being one of the most common categories of errors. Moreover, the study revealed that first-year students believe that learning grammar implies memorizing patterns, second-year learners feel that memorization does not guarantee accurate use of a rule, and advanced learners seem more concerned about the acquisition of vocabulary than grammar. Finally, beginners lack metalinguistic awareness to describe language difficulties; most learners were vague when describing language problems.

The focus of the current study is the analysis of the misuse of articles, one of the most pervasive types of mistakes. The longitudinal approach allowed the author to address the following research questions:

1. What are the most common types of article errors at different levels of language proficiency?

2. How frequent are they?

3. Is there evidence of significant decrease in the percentage of any of the types of errors as the students advance in the program? 


\section{Methodology}

\subsection{Participants}

The present study was conducted at the University of Costa Rica, a large public university. The participants were 159 undergraduates in the BA in English or the BA in Teaching English as a Foreign Language programs. Their ages ranged from 18 to 22. In this cross-sectional study, eight sections were randomly selected. Each of the groups represented one of the eight semesters in the two BA programs offered by the university. First-semester students were assumed to be beginners while eighth-semester students were considered to be advanced. At the time of data collection, the students were half way into the semester.

\subsection{The Data}

The present study is the third in a series about the frequency of language errors. The data used in the study consisted of eight groups of compositions written by the participants as regular part of their schoolwork. Some of these examples of academic writing were produced in class while others were assignments completed at home. To keep the data confidential, the students were identified by a number. Compositions were considered to be very fitting for this type of analysis because they provide ample context to determine appropriate use and to establish intended meaning.

\subsection{Analysis of the Data}

The 159 compositions were carefully reread, and all errors concerning the article system were recorded. All other errors, grammatical or of any other type, were disregarded. For each group, a list of errors was compiled, indicating the subject's assigned number.

The classification of errors is not always straightforward. Quite often a researcher is uncertain about whether a given error is an article problem or rather lack of proficiency in another grammar area. Therefore, since the focus of this study was the article system in English, a new analysis of the data was conducted to make certain that all errors that involved the misuse of an article were included. Sentence [a] is an example of an error that was not considered an article problem in the original analysis. It is important to point out that all the examples used in the present study are verbatim. Article problems are presented in italics to highlight the type of inaccuracy.

a. LM-1245 (subject 3): In the first group are comics that critic the careless interest that the society shows to important problems, such as pollution water's problem, and the ozone layer problem.

A better rendition of the italicized portion of the sentence above is "the water pollution problem." In the sentence written by the learner an article is missing. However, what seems to be the main difficulty is the learner's inability to use a noun as a modifier of another noun (water pollution). Instead, the learner incorrectly uses a possessive structure which could very well be the result of interference from the native language (la contaminación del agua). Nevertheless, in the present study, this inaccuracy was classified as an article error since one was missing. 
Another type of problem arises when dealing with the difference between count and non-count nouns as in the following example:

b. LM-1002 (subject 26): The money doesn't buy the most important things the love and the health.

It has been argued that noun countability is an important component in determining the appropriate choice of articles, as are referent specificity and hearer's knowledge (Goto Butler, 2002: 455-56). If an L2 learner is unable to determine whether a noun is countable or not in a given context, he or she is likely to make mistakes in article choice. However, in this study errors like the one in $b$ above were considered article problems.

The second step was to classify the article errors into three groups: unnecessary articles (overuse), missing articles (underuse), and wrong articles, that is, the inappropriate choice of an article or the use of a different word class. This analysis was done by individual and by group. Finally, a master list was compiled to include all the population.

\section{Findings}

Table 3 supplies a general overview of the errors concerning the use of the article system. The first column provides the group, the second column gives the ranking of article errors among all grammar errors made by that particular group as discussed in Hasbún, 2007, the third column is the actual number of article errors made by the group in the new analysis (raw score), and the last one is the percentage that article errors represent in the total number of grammar errors made by the students in each group. This last column is vital to the understanding of the problem because, in the present study, raw scores are not comparable since there are different numbers of students in each group, and the participants wrote essays of different lengths.

Table 3: Errors Concerning the Use of Articles

\begin{tabular}{|l|c|c|c|}
\hline Group & $\begin{array}{l}\text { Rank Among All } \\
\text { Errors }\end{array}$ & Raw Scores & $\begin{array}{l}\text { Percentage of Total } \\
\text { Number of Errors }\end{array}$ \\
\hline $\begin{array}{l}\text { LM-1001 } \\
\mathbf{n = 1 8}\end{array}$ & Second & 28 & $13.64 \%$ \\
\hline $\begin{array}{l}\text { LM-1002 } \\
\mathbf{n = 2 6}\end{array}$ & Second & 37 & $15.71 \%$ \\
\hline $\begin{array}{l}\mathbf{L M - 1 2 3 5} \\
\mathbf{n = 2 2}\end{array}$ & Second & 33 & $15.28 \%$ \\
\hline $\begin{array}{l}\mathbf{L M - 1 2 4 5} \\
\mathbf{n = 1 8}\end{array}$ & Second & 19 & $13.39 \%$ \\
\hline $\begin{array}{l}\mathbf{L M}-\mathbf{1 3 5 2} \\
\mathbf{n = 1 3}\end{array}$ & Third & 35 & $12.01 \%$ \\
\hline $\begin{array}{l}\mathbf{L M}-\mathbf{1 3 6 2} \\
\mathbf{n = 2 2}\end{array}$ & First & 33 & $13.93 \%$ \\
\hline $\begin{array}{l}\mathbf{L M}-\mathbf{1 4 7 2} \\
\mathbf{n = 2 3}\end{array}$ & Second & 15 & $16.65 \%$ \\
\hline $\begin{array}{l}\mathbf{L M}-1482 \\
\mathbf{n = 1 7}\end{array}$ & \multicolumn{2}{|c|}{} \\
\hline
\end{tabular}


Table 3 shows that article errors are among the three most frequent types of grammar errors for all the groups. They represent from $12.01 \%$ to $16.65 \%$ of the total number of errors. The percentage seems to be quite stable. In fact, there is no evidence of significant decrease in the percentage of errors as a result of instruction since the most advanced group has the highest percentage (16.65\%). This highlights the fact that, while other types of grammar errors tend to subside as learners advance, article misuse tends to persist regardless of formal training. This finding lends support to Dulay, Burt and Krashen's (1982) claim that since the rules governing the use articles are so complicated, they are seldom successfully acquired. These authors add that in the rare cases in which they are, the process is subconscious. This latter statement is probably not shared by most linguists and teachers now. In fact, they would most likely concur with the idea that serious efforts need to be made to find more useful ways to help learners acquire the article system in English. Fotos and Hinkel (2007: 131) argue that "most current pedagogy now includes both meaning-focused instruction and FFI [form-focused instruction], the first referring to purely communicative activities, and the second to activities promoting learner awareness of target grammar forms in input and production of the forms in output." Quite possibly, this is what the population needs in order to make significant progress.

Table 4 classifies article errors into three types of contexts: where an unnecessary article is supplied, where a required article is missing, and where a wrong article or another word such as a preposition is used instead of the correct article. The following are examples of the first type:

c. LM-1001 (subject 6): The most important activity is the surf.

d. LM-1245 (subject 17): It almost can be seen as a mirror of the society because of the topics they write about.

e. LM-1362 (subject 15): The government has to pay for expensive surgeries such as an organ transplants because health is a universal right.

Examples of the second category are

f. LM-1362 (subject 16): This action is done on behalf of the government and CCSS by taken nine percent (9\%) of $\theta$ money for payments to health insurance.

g. LM-1472 (subject 9): The use of figurative language in this poem points to $\theta$ beauty and greatness of nature.

h. LM-1001 (subject 9): For $\theta$ diet be healthy you have to eat fruits and vegetables too.

Examples of the third category are

i. LM-1362 (subject 1): It can be easier to pay a monthly rate for a public medical insurance that to pay a big bill in for any private or public health help in an specific moment.

j. $\quad$ LM-1352 (subject 6): The results of this experiment show the special qualities that you expect of an special teacher.

k. LM-1002 (subject 19): When you are going to choose an university you have to get information about the options do you have.

1. LM-1472 (subject 20): On the other hand, the religious motif is utilized to reinforce the persona's point of view against the passivity of humankind towards nature. 
m. LM-1001 (subject 2): Minimum you need to have three times at day for eats and eat little portions of each thing.

n. LM-1002 (subject 18): You have to pass one test in order to study a career, and most people do not pass it.

Examples [i], [j] and [k] are grammar errors probably triggered by phonological inaccuracy. Consonant clusters in syllable-initial position present a challenge for Spanish speakers since Spanish allows only limited clustering to occur. In fact, in Spanish /s/ is never followed by another consonant at the beginning of a word. Example [1] is a mistake because the definite article is used in a situation where the indefinite article is required since the noun motif was mentioned for the first time. In [m] the preposition at is used instead of the indefinite article in an idiomatic expression. Finally, in [n] a cardinal number is used. This mistake was most likely prompted by the fact that, in Spanish, there is no distinction between the indefinite article and the number one.

Table 4: Summary of Article Errors by Type

\begin{tabular}{|c|c|c|c|c|}
\hline Course & $\begin{array}{c}\text { Total Number of } \\
\text { Article Errors }\end{array}$ & $\begin{array}{c}\text { Type of Article } \\
\text { Errors }\end{array}$ & $\begin{array}{c}\text { Number of Errors } \\
\text { per Type }\end{array}$ & $\begin{array}{c}\text { Percentage of } \\
\text { Errors per Type }\end{array}$ \\
\hline \multirow{3}{*}{ LM-1001 } & \multirow{3}{*}{39} & unnecessary article & 20 & $51.28 \%$ \\
\hline & & missing article & 12 & $30.76 \%$ \\
\hline & & wrong article / word & 7 & $17.94 \%$ \\
\hline \multirow{3}{*}{ LM-1002 } & \multirow{3}{*}{54} & unnecessary article & 30 & $55.55 \%$ \\
\hline & & missing article & 19 & $35.18 \%$ \\
\hline & & wrong article / word & 5 & $9.25 \%$ \\
\hline \multirow{3}{*}{ LM-1235 } & \multirow{3}{*}{46} & unnecessary article & 19 & $41.30 \%$ \\
\hline & & missing article & 25 & $54.34 \%$ \\
\hline & & wrong article / word & 2 & $4.34 \%$ \\
\hline \multirow{3}{*}{ LM-1245 } & \multirow{3}{*}{54} & unnecessary article & 30 & $55.55 \%$ \\
\hline & & missing article & 19 & $35.18 \%$ \\
\hline & & wrong article / word & 5 & $9.25 \%$ \\
\hline \multirow{3}{*}{ LM-1352 } & \multirow{3}{*}{34} & unnecessary article & 20 & $58.82 \%$ \\
\hline & & missing article & 11 & $32.35 \%$ \\
\hline & & wrong article / word & 3 & $8.82 \%$ \\
\hline \multirow{3}{*}{ LM-1362 } & \multirow{3}{*}{59} & unnecessary article & 29 & $49.15 \%$ \\
\hline & & missing article & 21 & $35.59 \%$ \\
\hline & & wrong article / word & 9 & $15.25 \%$ \\
\hline \multirow{3}{*}{ LM-1472 } & \multirow{3}{*}{58} & unnecessary article & 24 & $41.37 \%$ \\
\hline & & missing article & 23 & $39.65 \%$ \\
\hline & & wrong article / word & 11 & $18.96 \%$ \\
\hline \multirow{3}{*}{ LM-1482 } & \multirow{3}{*}{25} & unnecessary article & 10 & $40.00 \%$ \\
\hline & & missing article & 13 & $52.00 \%$ \\
\hline & & wrong article / word & 2 & $8.00 \%$ \\
\hline
\end{tabular}


Table 4 highlights the fact that, for these learners, the most common problem tends to be the use of an article where one is not required. Overuse was also found by García Mayo (2008) whose learners were native Spanish speakers like the ones in the present study. However, results are not comparable since she exclusively focused on the acquisition of nongeneric uses of the article the. In her study, the overuse of the decreased significantly as the learners' English proficiency improved. In the present study, there is no clear evidence of such behavior because overuse of articles persists even at the more advanced stages of acquisition. In addition, García Mayo (2008:550) argues that "the overuse of the is strongly influenced by [the learners'] L1." This is an interesting claim that deserves attention.

In English, the Zero article $(\theta)$ typically occurs with plural nouns, noncountable nouns or proper nouns although there are other situations in which this happens, especially in fixed phrases. In contrast, in Spanish, "the definite article goes with mass nouns and plural count nouns that are used with a general meaning" causing interference (Swan and Smith, p. 104). Therefore, at least some of the students' overuse of the definite article might be attributed to the influence of Spanish, the learners' native language.

In a study conducted by Master (1994: 232), he found that $\theta$ with plural count nouns attained higher accuracy levels than $\theta$ with non-count nouns.

The following are examples of mistakes concerning the overuse of the definite article with mass nouns:

o. LM-1362 (subject 6): Honest and hard working people die just because they are not rich to pay for the care that they need, so where is the justice? (por lo tanto, ¿dónde está la justicia?)

p. LM-1472 (subject 13): Instead of respecting the nature, we are destroying the forest. (En vez de respetar la naturaleza, estamos destruyendo el bosque.)

In examples $[\mathrm{q}]$ and $[\mathrm{r}]$, plural count nouns which are used with a general meaning are preceded by the definite article as the rule applies in Spanish.

q. LM-1352 (subject 13): The more importance people give to the characteristics of exemplary teachers, the more likely is that the teachers will be motivated to sharpen their own dexterities.” (Entre más importancia le dé la gente a las características de los maestros ejemplares, más probable será que los maestros se vean motivados a desarrollar sus propias destrezas.)

r. LM-1472 (subject 2): Air pollution, water contamination, nuclear waste etc. are worries for the industrialized countries. (La contaminación del aire, la contaminación del agua, los desechos nucleares son preocupaciones para los países industrializados.)

\section{Conclusions and Teaching Implications}

Results from this kind of study can suggest focal points for instruction and address the errors that are most common to the target population. They also focus more specifically on sub-groups within the error types. Article errors occur frequently enough in these learners' written production to be worthy of classroom attention and to justify further research in this area. 
With respect to the first two research questions, it can be concluded that the most common type of article errors at different levels of language proficiency tends to be the overuse of articles. That was true for six out of the eight groups. It can be argued that this is due, at least in part, to native language interference. As to the third question, there is some evidence of decrease in the overuse of articles as the students advance in the program, but it does not seem to be very significant. For the most part, for the first six groups, overuse of articles accounts for roughly $50 \%$ of the errors while, in the last two, the percentage is closer to $40 \%$.

It is safe to conclude that, by the end of the BA, there is no complete acquisition of the article system. An obvious answer to this problem is the recycling of this topic along the program. An examination of the syllabi of the first introductory language courses, LM-1001 and LM-1002, as well as the four required grammar courses in the BA programs at the School of Modern Languages reveals that recycling is not systematic. Articles are introduced in LM1001. However, the textbook includes only the rule referred to as "first mention, subsequent mention." There are a couple of exercises in this textbook, but the supplementary material does not include any additional practice. It is important to point out that this particular rule is not especially difficult because the same applies in the students' native language. The following semester, in LM-1002, there is no formal teaching of articles.

In LM-1234, the first grammar course that the students take during their sophomore year, articles are dealt with in detail. The textbook used Basic English syntax (Flores, Alfaro and Flores, 2002: 27-40) includes a chapter devoted to determiners which discusses the main rules that govern the use of the article system in English and provides twelve exercises for practice. The following semester, in LM-1244, there is no formal teaching of articles. In LM-1353, Morphosyntax I, the learners study a chapter called "The structure class," which includes a five-page section on determiners in general. However, this section has only one exercise whose goal is the identification of determiners in six sentences. The next semester, in LM-1363, Morphosyntax II, articles are not addressed. Finally, during the senior year, there are no grammar courses. In conclusion, students practice articles and are evaluated on their use in only one course. Perhaps more work is necessary.

Although articles are difficult to teach and to acquire because there are many factors that intervene in their use and there are many high-frequency fixed phrases that need to be memorized as individual items, efforts need to be made to tackle the problem. Teachers need to raise awareness of the general rules that apply and encourage learners to pay attention to special situations on their own. Grammatical awareness enhances comprehension because it provides information that is helpful for making sense of input. It helps learners notice the gaps in their output and draws attention to their problem areas.

\section{Notes}

1. In this respect, Yule (1998: 25) argues that since in speech the difference between unstressed a (n) and $\theta$ is hardly noticeable and that for L1 and L2 learners the indefinite article is probably not heard in the beginning stages of acquisition, the indefinite article is acquired later than the definite article.

2. Classifying is a process by which we name a thing (or things) as belonging to a class of objects. We talk about the thing as a member of a category. Yule (1998: 33) 
3. Identifying is a process by which we refer to a thing (or things) as distinct from other members of the same category or class of objects. It has a distinguishing effect. Yule (1998: 33)

4. Long, 1991 (as cited in Doughty and Williams, 1998:4-5) explains focus on form as what a teacher does when he or she "draws students' attention to linguistic elements as they arise incidentally in lessons whose overriding focus is on meaning or communication." Focus on form can also be planned rather than incidental when triggered by an analysis of the learners' needs, that is, when a language feature has been identified as problematic.

\section{References}

Celce-Murcia, Marianne and Diane Larsen-Freeman. 1999. The grammar book: An ESL/EFL teacher`s reference. Second edition. Boston: Heinle \& Heinle.

Doughty, Catherine and Jessica Williams. 1998. Focus on form in classroom second language acquisition. New York: Cambridge University Press.

Doughty, Catherine and Jessica Williams. 1998. "Pedagogical choices in focus on form.” In Doughty and Williams (eds.) 197-261.

Dulay, Heidi, Marina Burt and Stephen Krashen. 1982. Language two. Nueva York: Oxford University Press.

Flores Mora, Berta, Vilma Alfaro Murillo and Marco Flores Mora. 2002. Basic English syntax. San José: Editorial de la Universidad de Costa Rica.

Fotos, Sandra and Hossein Nassaji. (Eds.). 2007. Form-focused instruction and teacher education: Studies in honour of Rod Ellis. Oxford: Oxford University Press.

Fotos, Sandra and Eli Hinkel. 2007. "Form-focused instruction and output for second language writing gains.” In Fotos and Hossein (eds.) 131-143.

Frodesen, Jan and Janet Eyring. 2003. Grammar dimensions 4a. Cambridge: Heinle \& Heinle.

García Mayo, María del Pilar. 2008. "The acquisition of four nongeneric uses of the article the by Spanish EFL learners.” System 36: 550-565.

Goto Butler, Yuko. 2002. Second language learners' theories on the use of English articles. An analysis of the metalinguistic knowledge used by Japanese students in acquiring the article system. Studies in Second Language Acquisition. 24: 451: 480.

Hasbún, Leyla. 2007. "Fossilization and acquisition: A study of learner language." Revista de Filología y Lingüística de la Universidad de Costa Rica. 33 (1): 113-129. 
Hasbún, Leyla. 2009. "Teacher and learner perceptions of language-learning problem areas." Revista de Lenguas Modernas. 10: 443-462.

Hawkins, John A. 1978. Definiteness and indefiniteness: A study in reference and grammaticality prediction. London: Croom Helm.

Leech, Geoffrey and Jan Svartvik. 1975. A communicative grammar of English. Essex: Longman.

Liu, Dilin and Johanna Gleason. 2002. "Acquisition of the article the by nonnative speakers of English." Studies in Second Language Acquisition, 24 (1): 1-26.

Master, Peter. 1990. “Teaching the English articles as a binary system.” TESOL Quarterly, 24 (3): 461-478.

Master, Peter. 1994. "Effect of instruction on learning the English article system." In Terence Odlin (ed.), 229-252.

Master, Peter. 2002. “Information structure and English article pedagogy.” System, 30: 331-348.

Nattinger, James and Jeanette DeCarrico. 1992. Lexical phrases and language teaching. New York: Oxford University Press.

Odlin, Terence (ed.) 1994. Perspectives on pedagogical grammar. New York: Cambridge University Press.

Pica, Teresa. 2007. “Time, teachers, and tasks in focus on form instruction.” In Fotos, Sandra \&, Hossein Nassaji. (Eds.), 161-175.

Schmitt, Norbert. 2002. Vocabulary in language teaching. New York: Cambridge University Press.

Swan, Michael and Bernard Smith. 1987. Lerner English: A teacher's guide to interference and other problems. New York: Cambridge University Press.

Yule, George. 1998. Explaining English grammar. New York: Oxford University Press. 